\title{
Factors behind loyalty in banking - a study based on state-owned commercial banks in Bangladesh
}

\author{
Serajul Islam, A. M. Shahabuddin and \\ Najneen Jahan Chowdhury \\ Department of Business Administration \\ International Islamic University Chittagong, Bangladesh
}

\begin{abstract}
This paper focuses on the causes of customer satisfaction and its relationship with loyalty in state-owned banking in Bangladesh. The study was conducted in ten branches of six stateowned commercial banks in Chittagong metropolitan area of Bangladesh. Some of the most influencing factors of loyalty have been identified in the study such as having understanding the specific needs of their customers; providing services timely, caring to customers, having required knowledge and skill of employees to perform the services and so on. This study provides some guidelines for developing customer loyalty in banking services.
\end{abstract}

Keywords Customer, Loyalty, Recovery, Satisfaction, Service, Quality

Paper type Research paper

\section{Introduction}

With the passage of time, the competition in banking sector is growing tremendously. To keep in the pace, the banking sector needs to focus on various aspects of service quality. Basically, customers take services from the banks repeatedly if they are satisfied with the existing services. In Bangladesh, there are fifty seven Scheduled Banks consisting of six state-owned Commercial Banks, two specialized banks, forty commercial banks run by privately and nine foreign banks. State-owned commercial banks are lagging behind in the market competition because their services are not up to the mark and causes dissatisfaction to the customers. Comparatively private and foreign banks provide more quality service to the customers and as such,

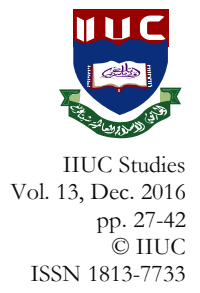




\section{IIUC STUDIES, 13}

they are going ahead earning profits and increasing market shares as well. Here a research will reveal facts and various aspects of loyalty which may come out after discussion with the customers. Service qualities, service recovery, willingness to continue and recommend the bank to others are the various aspects of loyalty. All the factors are closely related with the service and satisfactions of the customers of state-owned commercial banks. The objectives of the present study are; analyzing causes of satisfaction in state-owned banking service, finding the relationship of customer satisfaction with loyalty in state-owned banking in Bangladesh and to know the relationship of recovery with loyalty.

\section{Literature review}

Research, related with customer loyalty, has highlighted how significant existing customer can be for a bank. But whether a customer may buy repeatedly from a bank surely depends on whether the circumstances allow him or not. When service meets the customers need properly customers will be satisfied. Zeithaml (2003) described customer satisfaction as the sense of fulfillment of needs, contentment response of a customer, feelings of pleasure associated with happiness, delight, and sense of relief. Some researchers (Szymigin \& Carrigan, 2001 cited in Thakur, 2011) announced that loyalty is actually a feeling of association of a consumer to a product or a brand which results in repeat purchase.

However, Bloemer and Kasper (1995) cited in Mosahab et al. (2010) interpreted loyalty is not only confined to repeated purchasing behavior but also it is the commitment of customers that demonstrate repurchasing behavior other than loyalty. Ennew and Binks (1996) further cited in Kheng (2010) stated that the high costs of switching, lack of differentiation of alternatives, time, money or location constraints which are not related to loyalty.

Customers' attitudes comprised customer loyalty. According to Cronin and Taylor (1992) cited in Dhandabani (2010) and Thakur (2011) "components of attitude are represented through repurchase intention, purchasing additional products or services from the same company, willingness to recommend the company to others, demonstration of commitment to the company by resisting to switch 
to another competitor and willingness to pay a price premium (Zeithaml, Berry \& Parasuraman, 1996 cited in Thakur, 2011)".

Dhandabani (2010) opined for service loyalty that customers' satisfaction leads to customer's loyalty indirectly. His findings recommended that a systematic assessment of quality service by managers of the banks will lead customer loyalty.

Afsar et al. (2010) argued that banks need close relationship with the customers and managers should understand influential factors that lead to loyalty. They examined and found that prime importance should be given to various aspects of service quality, trust, switching cost, commitment and satisfaction.

On the other hand, satisfied customers may switch to other banks if competitor provides better services because they lack the trust commitment and attachment with the provider's services. This may be said as false loyalty which comes from the factors as switching costs. Internet evolution has made it much more difficult to retain a customer and to gain a truly loyal customer (Afsar et al., 2010).

Jahiruddin and Haque (2009) surveyed in Bangladesh. The study suggested that banks should reduce procedural complexities and ensure prompt delivery of services. Islam and Ahmed (2005) identified service quality factors as personal attention to the clients, error free records, safety in transactions, and tangible physical facilities.

Colgate and Hedge (2001) found several switching reasons if complains are not handled properly after investigating in Newzeland and Australian banks. Michel (2001) identified that service recovery as immediate efforts to minimize bad effects of service assessments. Khondaker, Saifuddin, and Zaman. (2011) in their research on stateowned banks identified some factors of customer satisfaction. However, service recovery and loyalty were not focused on the study. However, there are very limited studies available in the context of the state-owned banks of Bangladesh with reference to service recovery and this leads to the following research.

\section{Methodology}

At the very outset of the learning a rigorous review of literature has been conducted. These incorporated books, publications and periodicals associated with service loyalty in banking. The study was 
conducted in the location of Chittagong Metropolitan Area in 10 branches of 6 state-owned commercial banks. The total number of sample size for this learning was 50 that were worn out of 250 customers using convenience sampling method. A self-created questionnaire was prepared to collect prime data in view of objective of the learning. A Likert type scale was applied to pace the responds on the analysis. Five points were set to a response acknowledged as 'strongly disagree'; four points set to 'somewhat disagree', and the likely. The questionnaire was distributed only among the customers of the State-owned banking sectors in Chittagong metropolitan area. The interviewees were individually queried and the questionnaires were filled in by the interviewer depending on the responses of the interviewees. Of the number of issues to affect loyalty, the succeeding twelve issues have been preferred for the study purpose : Bank's corporal services are looking attractive, Personnel are decent by clothed and looking smart, Personnel are polite, Provide services timely, Perform services accurately, Prompt services to customers, Personnel have the required knowledge and skill to perform the services, Willingness to help customers, Realize the exact desires of their clients, Bank offer a complete range of services, Caring and individual attention to customers, and Creating customers believe protected and sound in dealings. After collecting data frequency distribution, percentage of frequency and lastly average score of each variable was estimated.

\section{Findings of the study}

To get a clear picture and wide idea regarding satisfaction and loyalty and also to identify the factors influencing loyalty, various service quality aspects have been introduced in the questionnaire.

\subsection{Service quality aspects}

In the questionnaire 12 items were included, based on the aforesaid quality dimensions mentioned in the methodology as well as in the literature review to find out respondents' agreement or disagreement regarding these quality aspects and these features are also considered important in the formation process leading to overall satisfaction. The findings are presented in the following tables: 


\section{Factors behind loyalty in banking 31}

Table 1: Bank's corporal services are found attractive

\begin{tabular}{lccc}
\hline \multicolumn{1}{c}{ Degree of satisfaction } & No of respondents & Percentage (\%) & Score \\
\hline Strongly agree & 10 & 20 & 10 \\
Somewhat agree & 13 & 26 & 26 \\
No comment & 3 & 6 & 9 \\
Somewhat disagree & 20 & 40 & 80 \\
Strongly disagree & 4 & 8 & 20 \\
Total & 50 & 100 & 145 \\
Average score & & & 2.90 \\
\hline
\end{tabular}

Source: Field survey

Though physical facilities of bank are one of the vital determining factors behind service loyalty, majority (54\%) of the sample customers of state-owned banks are found that physical facilities of bank is not that much appealing to become a loyal patron.

Table 2: Personnel are decently clothed and look smart

\begin{tabular}{lccc}
\hline Degree of satisfaction & No of respondents & Percentage $(\%)$ & Score \\
\hline Strongly agree & 20 & 40 & 20 \\
Somewhat agree & 27 & 54 & 54 \\
No comment & 3 & 6 & 9 \\
Somewhat disagree & & & \\
Strongly disagree & 50 & 100 & 83 \\
Total & & & 1.66 \\
Average score & & &
\end{tabular}

Source: Field survey

It is evident from the above table that near about $100 \%$ customers are in the opinion that if the personnel are well dressed and behave professionally can secure customers' service loyalty.

Table 3: Personnel are polite

\begin{tabular}{lccc}
\hline Degree of satisfaction & No of respondents & Percentage $(\%)$ & Score \\
\hline Strongly agree & 3 & 6 & 3 \\
Somewhat agree & 34 & 68 & 68 \\
No comment & 10 & 20 & 30 \\
Somewhat disagree & 3 & 6 & 12 \\
Strongly disagree & 50 & 100 & 113 \\
Total & & & 2.26 \\
Average score & & & \\
\hline
\end{tabular}

Source: Field survey

The present study reveals that $74 \%$ of the respondents feel that well-mannered personnel can help customers to become loyal clients. 


\section{IIUC STUDIES, 13}

Table 4: Provide services timely

\begin{tabular}{lccc}
\hline Degree of satisfaction & No of respondents & Percentage $(\%)$ & Score \\
\hline Strongly agree & 10 & 20 & 10 \\
Somewhat agree & 6 & 12 & 12 \\
No Comment & 10 & 20 & 30 \\
Somewhat disagree & 24 & 48 & 96 \\
Strongly disagree & - & - & - \\
Total & 50 & 100 & 148 \\
Average score & & & 2.96 \\
\hline
\end{tabular}

Source: Field survey

In the current scenario of loyalty in banking, right service at right time is the most important service quality aspects that in turns lead to customers' satisfaction and loyalty. State-owned banks fail to provide services timely which are represented by $48 \%$ of respondents.

Table 5: Perform services accurately

\begin{tabular}{lccc}
\hline Degree of satisfaction & No of respondents & Percentage $(\%)$ & Score \\
\hline Strongly agree & 14 & 28 & 14 \\
Somewhat agree & 20 & 40 & 40 \\
No Comment & 6 & 12 & 18 \\
Somewhat disagree & 10 & 20 & 40 \\
Strongly disagree & - & - & - \\
Total & 50 & 100 & 112 \\
Average score & & & 2.24 \\
\hline
\end{tabular}

Source: Field survey

Perform services accurately being an integral part of exposure of service loyalty has profound implication in exploring new markets of loyalty which is supported by $68 \%$ of respondents.

Table 6: Prompt services to customers

\begin{tabular}{lccc}
\hline Degree of satisfaction & No of respondents & Percentage $(\%)$ & Score \\
\hline Strongly agree & 13 & 26 & 13 \\
Somewhat agree & 16 & 32 & 32 \\
Neither agree nor disagree & 11 & 22 & 33 \\
Somewhat disagree & 10 & 20 & 40 \\
Strongly disagree & - & & - \\
Total & 50 & 100 & 118 \\
Average score & & & 2.36 \\
\hline
\end{tabular}

Source: Field survey

Prompt services are important for the customers to feel comfortable in getting services. It has been observed in our study that $58 \%$ customers get their services promptly. 
Factors behind loyalty in banking 33

Table 7: Personnel have the required knowledge and skill to perform the services

\begin{tabular}{lccc}
\hline Degree of satisfaction & No of respondents & Percentage $(\%)$ & Score \\
\hline Strongly agree & 17 & 34 & 17 \\
Somewhat agree & 7 & 14 & 14 \\
No Comment & 20 & 40 & 60 \\
Somewhat disagree & 3 & 6 & 12 \\
Strongly disagree & 3 & 6 & 15 \\
Total & 50 & 100 & 118 \\
Average score & & & 2.36 \\
\hline Source: Field & & &
\end{tabular}

Source: Field survey

Many customers (40\%) are confused about the personnel's required knowledge and skill to perform the services effectively. On the other hand $12 \%$ observed that there is a lack of knowledge and skill to provide services.

Table 8: Willingness to help customers

\begin{tabular}{lccc}
\hline Degree of satisfaction & No of respondents & Percentage $(\%)$ & Score \\
\hline Strongly agree & 7 & 14 & 7 \\
Somewhat agree & 30 & 60 & 60 \\
Neither agree nor disagree & 3 & 6 & 9 \\
Somewhat disagree & 10 & 20 & 40 \\
Strongly disagree & - & - & - \\
Total & 50 & 100 & 116 \\
Average score & & & 2.32 \\
\hline
\end{tabular}

Source: Field survey

Willingness to help customers has positive influence on customers' satisfaction. Only $(20 \%)$ of the sample respondents are in the opinion that state-owned banks are in lack to confirm keenness to help customers.

Table 9: Realize the exact desires of their clients

\begin{tabular}{lccc}
\hline Degree of satisfaction & No of respondents & Percentage $(\%)$ & Score \\
\hline Strongly agree & 6 & 12 & 6 \\
Somewhat agree & 14 & 28 & 28 \\
Neither agree nor disagree & 10 & 20 & 30 \\
Somewhat disagree & 10 & 20 & 40 \\
Strongly disagree & 10 & 20 & 50 \\
Total & 50 & 100 & 154 \\
Average score & & & 3.08 \\
\hline
\end{tabular}

Source: Field survey

Service loyalty is dependent on customers' satisfaction with fulfilling their specific needs. From the above table it is observed that only $40 \%$ of the sample customers are satisfied with their 


\section{IIUC STUDIES, 13}

specific needs whereas other $40 \%$ are not satisfied and rest $20 \%$ are neither satisfied nor dissatisfied.

Table 10: Bank offer a complete range of services

\begin{tabular}{lccc}
\hline Degree of satisfaction & No of respondents & Percentage $(\%)$ & Score \\
\hline Strongly agree & 10 & 20 & 10 \\
Somewhat agree & 18 & 36 & 36 \\
No Comment & 10 & 20 & 30 \\
Somewhat disagree & 6 & 12 & 24 \\
Strongly disagree & 6 & 12 & 30 \\
Total & 50 & 100 & 130 \\
Average score & & & 2.60 \\
\hline
\end{tabular}

Source: Field survey

The present study reveals that near about $50 \%$ customers are found in the opinion that banks fail to offer a complete range of services to the customers.

Table 11: Caring and individual attention to customers

\begin{tabular}{lccc}
\hline Degree of satisfaction & No of respondents & Percentage $(\%)$ & Score \\
\hline Strongly agree & 10 & 20 & 10 \\
Somewhat agree & 20 & 40 & 40 \\
Neither agree nor disagree & 6 & 12 & 18 \\
Somewhat disagree & 10 & 20 & 40 \\
Strongly disagree & 4 & 8 & 20 \\
Total & 50 & 100 & 128 \\
Average score & & & 2.56 \\
\hline
\end{tabular}

Source: Field survey

The present study has undertaken caring and individual attention to customers to address specific problems of customers to become loyal patron. About $40 \%$ of the customers are facing problem regarding caring of individual customer.

Table 12: Creating customers believe protected and sound in dealings

\begin{tabular}{lccc}
\hline Degree of satisfaction & No of respondents & Percentage $(\%)$ & Score \\
\hline Strongly agree & 15 & 30 & 15 \\
Somewhat agree & 20 & 40 & 40 \\
Neither agree nor disagree & 3 & 6 & 9 \\
Somewhat disagree & 7 & 14 & 28 \\
Strongly disagree & 5 & 10 & 25 \\
Total & 50 & 100 & 117 \\
Average score & & & 2.34 \\
\hline
\end{tabular}

Source: Field survey

Secured transaction is one of the vital determining factors influencing customer satisfaction. Majority $(80 \%)$ of the sample 
customers are found to be satisfied with this small chance of unsecured transaction.

Table 13: Ranking of the influencing factors behind loyalty based on scores

\begin{tabular}{clcc}
\hline Factors & Name of the Factors & Score & Rank \\
\hline 1 & Bank's corporal services are seeing attractive & 2.90 & 3rd \\
2 & Personnel are well dressed and appear neat & 1.66 & 11 th \\
3 & Personnel are polite & 2.26 & 9 th \\
4 & Provide services timely & 2.96 & 2nd \\
5 & Perform services accurately & 2.24 & 10 th \\
6 & Prompt services to customers & 2.36 & 6 th \\
7 & Personnel have the required knowledge and skill to & 2.36 & 6 th \\
8 & perform the services & 2.32 & 8th \\
9 & Willingness to help customers & 3.08 & $1 \mathrm{st}$ \\
10 & Realize the exact desires of their clients & 2.60 & 4 th \\
11 & Bank offer a complete range of services & 2.56 & 5 th \\
12 & Caring and individual attention to customer & 2.34 & 7 th \\
\hline
\end{tabular}

The factor ranking show that Factor-9: Realize the exact desires of their clients are the most significant factor influencing service loyalty of customers in state-owned banks. This has really reflected the actual picture of better loyal management of sample banks. The second most important factor is 'Provide services timely'. This factor is considered to be execution loyalty in sample banks substantial. The third important factor is Bank's corporal services are found attractive. This factor bears the evidence that loyalty in sample banks is lacking appropriate physical facilities of banks. The other factors considered by sample respondents in order of magnitudes are Bank offer a complete range of services, Caring and individual attention to customer, Prompt services to customers, Personnel have the required knowledge and skill to perform the services and so on.

The findings about service quality and satisfaction are shown in the following figure. 
Figure 1: Cross-tabulation results between service quality and customer satisfaction:

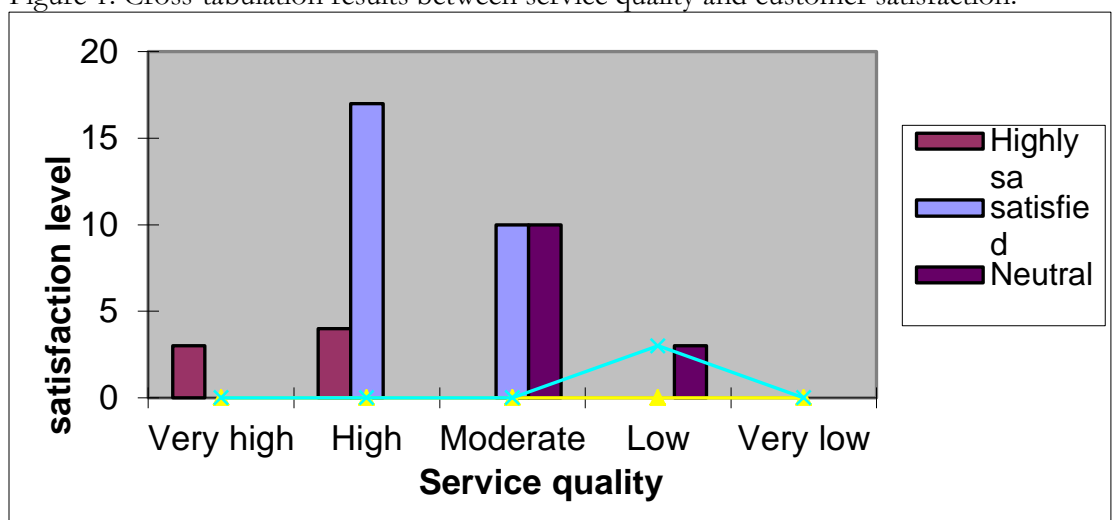

(Source: field survey)

The results of cross tabulation provide valuable information on complete agreement. From the above results it can be concluded that the judgment towards the level of service quality (based on the service quality dimensions) have great impact on satisfaction.

\subsection{Service recovery aspects}

In this study different types of service failure and recovery strategies were used. These were used to discover the extent of complaints, customers' perception regarding failure and what sort of service recovery strategies they prefer to receive against the problem as well the strategies usually adopted by the bank and also their level of satisfaction with the recovery strategies taken by the bank.

\section{Problems faced by the respondents}

The respondents were asked to identify the problems they faced dealing with the banks. Most of the problems were predetermined and included in the questionnaire and there was an option to mention the other problems (if they faced any) that was not included in the questionnaire. Findings regarding the service failure presented below: 
Figure 2: Frequency of service failures (problems)

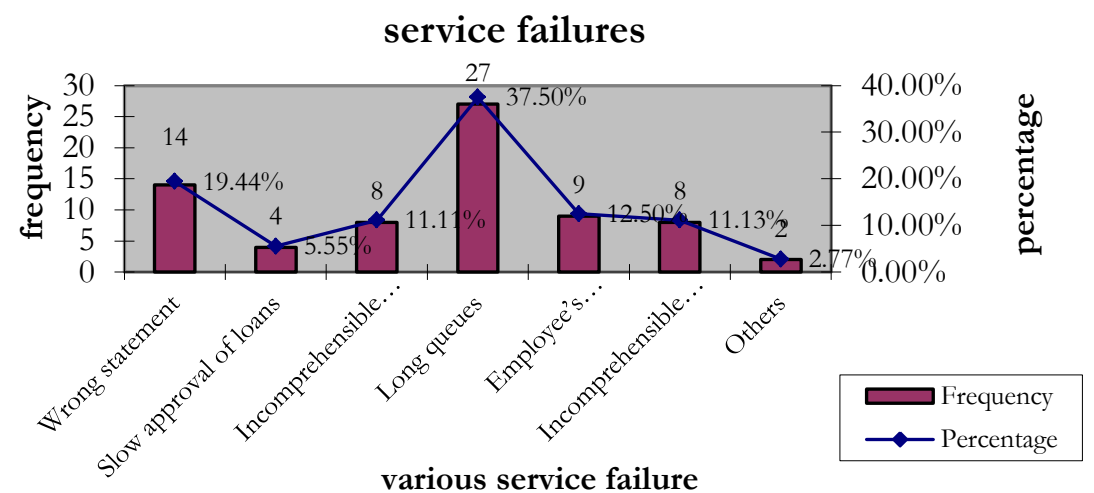

(Source: field survey)

The research data provided the evidence of several types of service failures such as long queues, wrong statement, and employee's unwillingness to help and so on. Most of the problems were predetermined by the earlier research and mentioned in the questionnaire along with an option "other" so that they can mention other problems, if they faced any dealing with the bank. These failures were of varying importance and it is also notable that less important failures become important when a customer actually experiences them. According to the findings the most common failures, in terms of magnitude, were "long queue" $(37.5 \%$ mentioned this problem) followed by "wrong statement" (19.44\% respondents mentioned). The survey also revealed another problem, not mentioned in the questionnaire that is delayed in sending statement. $2.77 \%$ respondent mentioned that the bank didn't send the statement timely.

\section{Service recovery strategies taken by banks}

After determining various service failures the respondents were asked to identify the recovery strategies taken by the bank to solve the problem(s). The findings are summarized in Table 14 
38 IIUC STUDIES, 13

Table 14: Frequency distribution of service recovery strategies

\begin{tabular}{lcc}
\hline Service recovery strategies & Frequency & $\%$ \\
\hline Immediate and speedy response & 8 & 12.5 \\
Caring and honest response & 14 & 21.87 \\
Correction & 4 & 6.25 \\
Explanation & 18 & 28.13 \\
Apologies & 14 & 21.87 \\
Compensation & 4 & 6.25 \\
Other & 2 & 3.13 \\
\hline
\end{tabular}

(Source: field survey)

Basically the recovery strategies applied by the bank depend on the nature of the problem arises during the transaction period or the post transaction period. Different types of strategies are suitable for different problems. According to Table 14 the widely used recovery strategy adopted by the bank is "explanation" and $28.13 \%$ respondents mentioned this followed by "caring and honest response" and "apologies". 21.87\% respondents pointed out that bank could usually apply the later two recovery strategies to solve the problem. The least applied recovery strategies were correction and compensation and only $6.25 \%$ mentioned that bank could take those strategies to solve their problems. On the other hand, 3.13\% respondents mentioned that their bank didn't take any recovery strategy to solve the problems.

\section{Service recovery and satisfaction}

Another cross-table has been introduced to identify the impact of service recovery on satisfaction and the findings are reported in the following table.

Table 15: Cross-tabulation results between service recovery and customer satisfaction

\begin{tabular}{|c|c|c|c|c|c|c|c|c|c|c|c|c|}
\hline \multirow[b]{3}{*}{$\begin{array}{l}\text { Service recovery } \\
\text { strategies }\end{array}$} & \multicolumn{12}{|c|}{ Customer satisfaction } \\
\hline & \multicolumn{2}{|c|}{1} & \multicolumn{2}{|c|}{2} & \multicolumn{2}{|c|}{3} & \multicolumn{2}{|c|}{4} & \multicolumn{2}{|c|}{5} & \multicolumn{2}{|c|}{ Total } \\
\hline & $\mathrm{F}$ & $\%$ & $\mathrm{~F}$ & $\%$ & $\mathrm{~F}$ & $\%$ & $\mathrm{~F}$ & $\%$ & F & $\%$ & $\mathrm{~F}$ & $\%$ \\
\hline Highly satisfied & - & - & - & - & - & - & - & - & - & - & - & - \\
\hline Satisfied & - & - & 13 & 42 & - & - & - & - & - & - & 13 & 42 \\
\hline Neutral & - & - & 3 & 10 & 9 & 28 & & & & & 12 & 38 \\
\hline Dissatisfied & - & - & - & - & - & - & 3 & 10 & - & - & 3 & 10 \\
\hline Highly dissatisfied & - & - & & & & & & & 3 & 10 & 3 & 10 \\
\hline Total & - & - & 16 & 52 & 9 & 28 & 3 & 10 & 3 & 10 & 31 & 100 \\
\hline
\end{tabular}


The results of cross tabulation also provide valuable information regarding the impact of service recovery on satisfaction, i.e. the respondents, who are satisfied with the service recovery strategies, they also expressed their overall satisfaction towards the bank and vice-versa. It can be concluded that, there appears to be a positive relationship between service recovery and satisfaction.

\subsection{Satisfaction and loyalty}

Frequency of respondents' opinion to continue with the bank is shown in the following table:

Table 16: Frequency of respondents' opinion to continue with the bank

\begin{tabular}{lllllllllllll}
\hline \multirow{2}{*}{ Respondents' Opinion } & \multicolumn{2}{c}{1} & \multicolumn{2}{c}{2} & & 3 & & 4 & \multicolumn{2}{c}{5} \\
\cline { 2 - 11 } & $\mathrm{F}$ & $\%$ & $\mathrm{~F}$ & $\%$ & $\mathrm{~F}$ & $\%$ & $\mathrm{~F}$ & $\%$ & $\mathrm{~F}$ & $\%$ \\
\hline $\begin{array}{l}\text { You will continue with this bank } \\
\begin{array}{l}\text { even if the service charge or } \\
\text { policies change somewhat }\end{array}\end{array}$ & 9 & 18 & 21 & 42 & 4 & 8 & 8 & 16 & 8 & 16 \\
\hline
\end{tabular}

Scale: $1=$ strongly agree, $2=$ somewhat agree, $3=$ neither agree nor disagree, $4=$ somewhat disagree, $5=$ strongly disagree. (Source: field survey)

In this regard it can also be noted that satisfied customers tend to be loyal with the bank regardless of changes in service charge or policies. Basically, the negative attitude comes from the dissatisfaction regarding service quality and dissatisfactory service recovery. From the above table, it can also be argued that a significant number of respondents expressed their loyalty towards the bank. This is due to the level of satisfaction. Those who are satisfied to the bank are usually willing to recommend the bank to others and also intend to continue with the bank even if the service charge as somewhat changed. The relationship between satisfaction and loyalty is presented below:

Table 17: Cross-tabulation results between customer satisfaction and intend to continue regardless of changes in policies or service charge.

\begin{tabular}{lcccccccccccccc}
\hline \multicolumn{8}{c}{ Continue with the bank even if the charge } \\
or policies change somewhat \\
\hline $\begin{array}{l}\text { Customer } \\
\text { satisfaction }\end{array}$ & $\mathrm{F}$ & $\%$ & $\mathrm{~F}$ & $\%$ & $\mathrm{~F}$ & $\%$ & $\mathrm{~F}$ & $\%$ & $\mathrm{~F}$ & $\%$ & $\mathrm{~F}$ & $\%$ \\
$\begin{array}{l}\text { Highly satisfied } \\
\text { Satisfied }\end{array}$ & 6 & 12 & - & - & - & - & - & - & - & - & 6 & 12 \\
& 3 & 6 & & 17 & 34 & - & - & 3 & 6 & - & - & 23 & 46
\end{tabular}


Continue with the bank even if the charge or policies change somewhat

\begin{tabular}{lcccccccccccc}
\hline Neutral & - & - & 6 & 12 & 3 & 6 & 6 & 12 & - & - & 15 & 30 \\
Dissatisfied & - & - & - & - & - & - & - & - & 3 & 6 & 3 & 6 \\
Highly dissatisfied & - & - & - & - & - & - & - & - & 3 & 6 & 3 & 6 \\
Total & 9 & 18 & 23 & 46 & 3 & 6 & 9 & 18 & 6 & 12 & 50 & 100 \\
\hline
\end{tabular}

Scale: $1=$ strongly agree, $2=$ somewhat agree, $3=$ neither agree nor disagree, $4=$ somewhat disagree, $5=$ strongly disagree. (Source: field survey)

This implies that loyalty is related to satisfaction and also there is a positive relationship between them.

The other cross-table is based on level of satisfaction and respondents intention to recommend the bank to others. The findings are reported below:

Table 18: Cross-tabulation results between customer satisfaction and their willingness to recommend the bank.

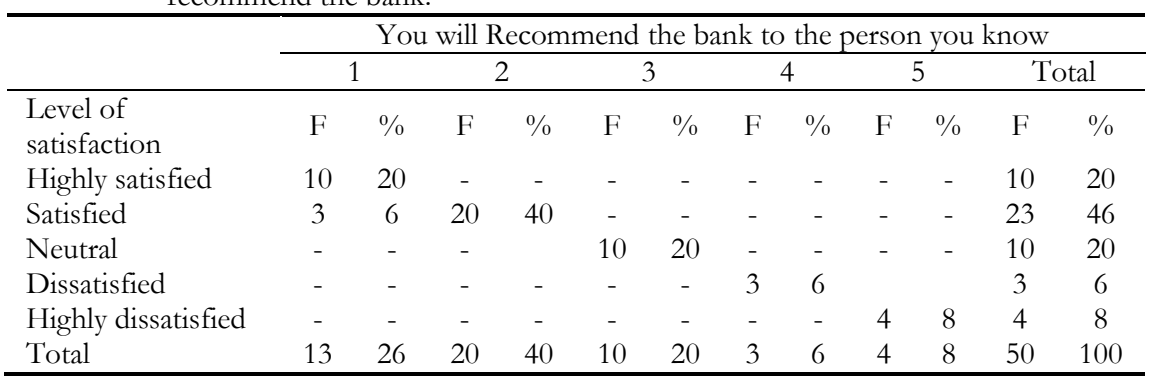

From the above Table it is clear that respondents, who are satisfied with the bank, are also interested to recommend the bank to others. Table also shows that $66 \%$ satisfied customers (either highly satisfied or satisfied) articulated their agreement to recommend the bank to others. From the above findings, it can be concluded that there is a strong (positive) relationship between satisfaction and loyalty and it is also apparent that satisfied customers want to continue with the bank as well as recommend it to others.

\section{Satisfaction and loyalty relationship}

The results of cross tabulation also provide important information regarding complete agreement i.e. the percentage of respondents whose satisfaction levels and willingness to continue and recommend are either highly satisfied and strongly agree (extremely 
likely), satisfied and somewhat agree (likely) or highly dissatisfied and strongly disagree (not at all likely), and complete disagreement i.e. highly satisfied and strongly disagree (not at all likely) or vice versa. The degree of complete agreement and disagreement are presented in the following Table.

Table 19: Degree of complete agreement and willingness to continue (even if the charges or policies change somewhat) and recommend the bank to others.

\begin{tabular}{lcc}
\hline Factor & $\begin{array}{c}\text { Complete } \\
\text { Agreement }(\%)\end{array}$ & $\begin{array}{c}\text { Complete Disagreement } \\
(\%)\end{array}$ \\
\hline $\begin{array}{l}\text { Satisfaction and intend to } \\
\text { continue }\end{array}$ & $\begin{array}{c}12+34+12+6+6=70 \\
\text { (Based on Table 5) }\end{array}$ \\
$\begin{array}{l}\text { Satisfaction and } \\
\text { willingness to recommend } \\
\text { the bank }\end{array}$ & $\begin{array}{c}20+40+20+8=88 \\
\text { (Based on Table 6) }\end{array}$ & Nil \\
\hline
\end{tabular}

(Source: field survey)

Values for complete agreement between satisfaction and loyalty range from $70 \%$ to $88 \%$ whereas the value for complete disagreement is zero. The results indicate that there exists a positive relation between level of satisfaction and loyalty (willingness to continue and recommend the bank to others have been considered as elements of loyalty) and an increase in one factor are likely to influence another.

\section{Conclusions}

The study found that respondents encounter various problems dealing with the state-owned banks of Bangladesh. Providing better quality was an addition earlier but it is now a requirement to survive in the banking industry. Service quality and service recovery strategies are the important antecedents of satisfaction. The various service quality dimensions realizes exact requirement of the clients and prompt delivery of the services has got the highest attention. Research also shows that service recovery strategies have great impact on satisfaction. The study was confined to Chittagong Metropolitan area. It may be found better result, if larger sample size including all the banks both foreign and local banks operating in Bangladesh were collected in the study. Provision for Premium quality service and well training is highly essential for attaining customer loyalty. 


\section{IIUC STUDIES, 13}

Customers have more strong beliefs on state-owned banks than private banks, they don't have that strong loyalty to their banks such as if they find better and prompt service from private banks, they will surely switch from their current banks. Therefore, there is enough scope for the banks to improve their service quality. Researchers and policy makers may discover means by which customer switching behavior can be predicted.

\section{References}

Afsar, B., Rehman, Z. U., Qureshi, J. A., \& Shahjehan, A. (2010). Determinants of customer loyalty in the banking sector: the case of Pakistan. African Journal of Business Management, 4(6), 1040-1047.

Akter, S., Upal, M., \& Hani, U. (2008). Service quality perception and satisfaction: a study over sub-urban public hospitals in Bangladesh. Journal of Services Research, (Special Issue, February), 125-146.

Colgate, M., \& Hedge, R. (2001). An investigation into the switching process in retail banking services. International Journal of Bank. Marketing, 19(4/5), 201-212.

Dhandabani, S. (2010). Linkage between service quality and customers loyalty in commercial banks. International Journal of Management \& Strategy, 1(1), 1-22.

Islam, N., \& Ahmed, E. (2005). A measurement of customer service quality of banks in Dhaka city of Bangladesh. South Asian Journal of Management, 12(1), 37-57.

Jahiruddin, A. T. M., \& Haque, R. (2009). Bank selection criteria of retail customers in Bangladesh: a study on Khulna city. Journal of Business and Management, 15(2), 159-170.

Kheng, L. L. (2010). The impact of service quality on customer loyalty: a study of banks in Penang, Malaysia. International Journal of Marketing Studies, 2(2), 57-66.

Khondaker, M. S., \& Mir, M. Z. (2011). Customer satisfaction measurement for the state-owned banks in the developing countries - The case of Bangladesh. Journal of Business and Policy Research, 6(2), 153-172.

Mosahab, R., Mahamad, O., \& Ramayah, T. (2010). Service quality, customer satisfaction and loyalty: a test of mediation. International Business Research, 3(4), 72-80.

Thakur, S. (2011). Service quality, customer satisfaction and customer loyalty: a study with special reference to Indian banking industries. The Journal of Sri Krishna Research \& Educational Consortium, 1(5), 83-93.

Zeithaml, V. A. (2003). Services Marketing (4th ed.). New Delhi: Tata McGraw-Hill Publishing Company Limited.

\section{Corresponding author}

Serajul Islam can be contacted at: serlambd@yahoo.com 